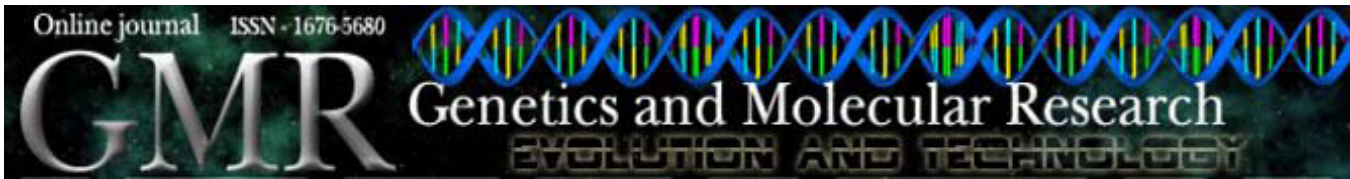

\title{
Pollen sources of the orchid bee Euglossa annectans Dressler 1982 (Hymenoptera: Apidae, Euglossini) analyzed from larval provisions
}

\author{
M. Cortopassi-Laurino ${ }^{1,3}$, A. Zillikens ${ }^{2,3}$ and J. Steiner ${ }^{3}$ \\ 'Departamento de Ecologia, Laboratório de Abelhas, \\ Universidade de São Paulo, São Paulo, SP, Brasil \\ ${ }^{2}$ Universität Tübingen, Medizinisch-Naturwissenschaftliches- \\ Forschungszentrum, Tübingen, Germany \\ ${ }^{3}$ Departamento de Biologia Celular, Embriologia e Genética, \\ Centro de Ciências Biológicas, Universidade Federal de Santa Catarina, \\ Florianópolis, SC, Brasil
}

Corresponding author: M. Cortopassi-Laurino

E-mail:mclaurin@usp.br and anne.zillikens@uni-tuebingen.de

Genet. Mol. Res. 8 (2): 546-556 (2009)

Received December 12, 2008

Accepted January 26, 2009

Published May 19, 2009

\begin{abstract}
In order to analyze the pollen resources used by the orchid bee Euglossa annectans, samples of larval provisions from cells under construction were taken from 12 different trap nests (wooden boxes) on Santa Catarina Island, southern Brazil. The 43 samples collected between 2002 and 2005 represented all months except December. Overall, 74 pollen types from 24 families were distinguished. Among the 26 pollen types that reached more than $10 \%$ in monthly means, the families Melastomataceae, Bromeliaceae, Ochnaceae, Fabaceae, and Myrtaceae were most frequently represented. The Shannon-Weaver diversity index $H^{\prime}$ for the 43 brood cells varied from $0.10-1.65$ and the annual diversity was 0.98 . Similarity indices ranged from 0 to 0.87 and were highest during spring and summer. The results characterize $E$. annectans as a polylectic species. Based on these data, we can conclude that Euglossa females may act as pollinators of many forest species.
\end{abstract}

Key words: Euglossa annectans; Pollen provisions; Trap nest; Atlantic rainforest; Polylectic foraging 


\section{INTRODUCTION}

Euglossa is the largest of five genera of orchid bees (Euglossini), with 103 described species occurring from northern Mexico to Paraguay and northern Argentina (Augusto and Garófalo, 2004). While many are thought to be solitary, the finding of more than one female per nest in E. annectans, E. cordata, E. hyacinthina, E. nigropilosa, and E. townsendi (Garófalo et al., 1998; Zillikens et al., 2003 [as E. stellfeldi], Soucy et al., 2003; Augusto and Garófalo, 2004; Otero et al., 2008) suggests some sort of social organization; however, they have never been considered to be eusocial (Zucchi et al., 1969). The record of the fossil E. moronei from Dominican amber confirms an age of this taxon of at least 20 million years (Engel, 1999).

The fact that the females of some species of euglossines accept trap nests facilitates the study of their life history, including the pollen sources collected for brood provisioning. Although euglossines are primarily famous for their males, which are the principal pollinators of many orchid species, both males and females also visit flowers of many other plants (Ramírez-Arriaga and Martínez-Hernández, 1998; Roubik and Hanson, 2004) to collect nectar, pollen and resin.

Euglossa annectans occurs in the Brazilian States of Espírito Santo, Minas Gerais, Rio de Janeiro, São Paulo, Paraná, and Santa Catarina and Paraguay (Moure et al., 2007) and nests in bamboo canes and other small natural or artificial cavities (Garófalo et al., 1998). Nests can be reused for up to five years and grow up to 259 cells in a single nest (Cortopassi-Laurino et al., 2008a,b).

In this study, we analyzed the pollen in larval provisions to identify the plant species representing the forage spectrum of $E$. annectans.

\section{MATERIAL AND METHODS}

We studied nests of $E$. annectans in trap nests consisting of pine wood boxes exposed in miconietum vegetation adjacent to secondary ombrophilous forest at two study sites, Unidade de Conservação Ambiental Desterro (UCAD) and Santo Antônio de Lisboa, on Santa Catarina Island (see Zillikens and Steiner, 2004, for details). Monthly means of temperature and precipitation were obtained from the site www.inmetro.gov. br (Figure 1).

From 12 nests, obtained between 2002 and 2005, 43 samples of the larval provision from brood cells under construction were taken with tooth picks. Aggregated nesting of several females within the same box allowed the collection of pollen from up to 10 brood cells being provisioned simultaneously. Pollen slides were prepared by suspending the pollen in water and mounting it with uncolored and fuchsine-stained glycerin jelly.

Pollen was identified by comparison with the reference collection of LANUFSC (Laboratório de Abelhas Nativas da Universidade Federal de Santa Catarina) and specific literature (Santos, 1963; Barth, 1989; Roubik and Moreno, 1991; Moreti et al., 2002). In case of morphologically indistinguishable pollen, the flowering period of the plants in question was also taken as a criterion for identification. When pollen had an aspect or size similar to a certain plant species or genus but collection date did not correspond to the flowering period, or when the occurrence of that species in the study area was unknown, 
they were identified as "type". Per slide a minimum of 300 pollen grains were counted and the proportions of every pollen type were calculated in percent and expressed as monthly means.

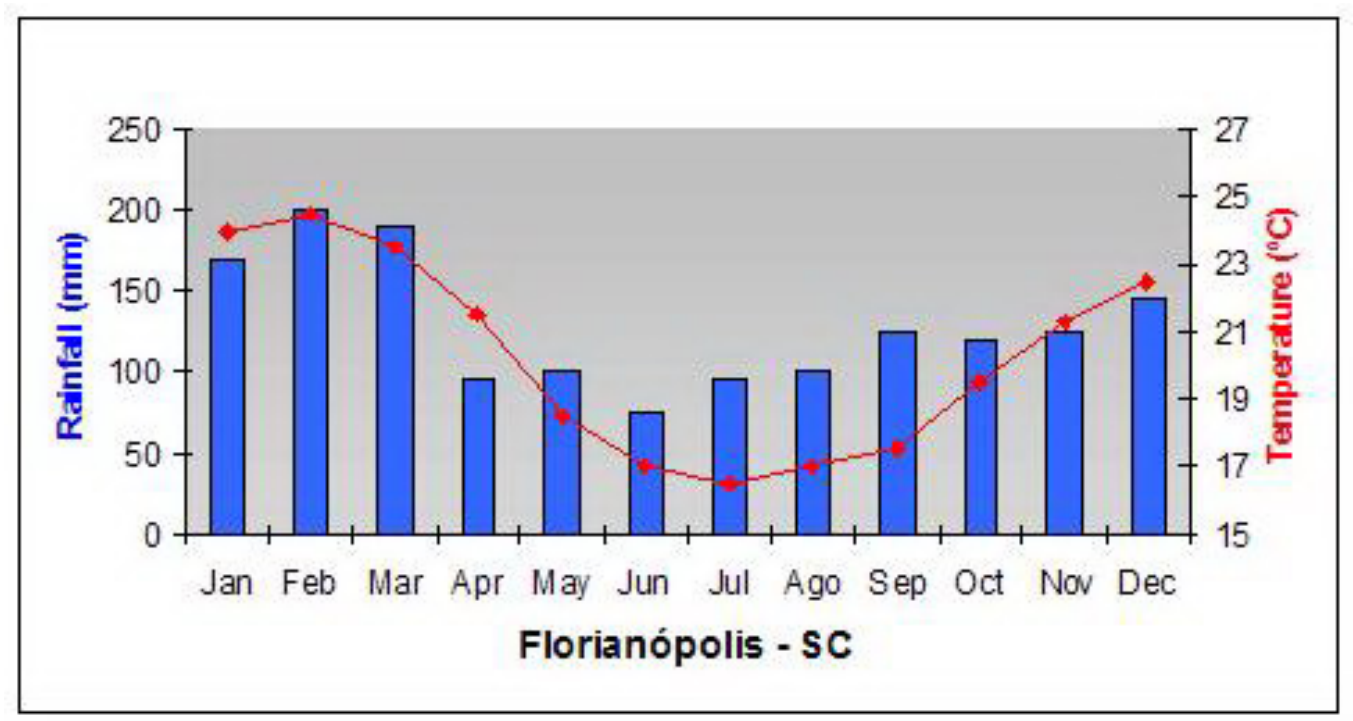

Figure 1. Monthly means of precipitation and temperature of Florianópolis, Santa Catarina Island, southern Brazil, for the period 1960-1990. Source: [www.inmet.gov.br].

\section{Statistical analysis}

The diversity index of Shannon-Weaver (H') (1949) was calculated for each sample (= brood cell). The index of similarity (Cody, 1974) was applied for pairs of brood cells of the same month.

\section{RESULTS}

Pollen samples from all months of the year except December were obtained and studied. The analysis of 13,644 pollen grains from 43 samples of larval provisions revealed a total of 74 pollen types, $26(35 \%)$ of which made up more than $10 \%$ in the monthly means (Table 1). Overall, pollen from plants of the families Melastomataceae, Bromeliaceae, Ochnaceae ("type Ouratea"), Fabaceae ("type Lathyrus"), and Myrtaceae was most frequent in the samples. Less frequent but still important were pollen from $\mathrm{Fa}$ baceae, Bignoniaceae, Lauraceae ("type Ocotea"), Euphorbiaceae, and Solanaceae (Figure 2). Pollen of the plant species "type Lathyrus", Clidemia hirta, Nidularium innocentii, "type Ouratea", Aechmea ornata and A. lindenii (Bromeliaceae), and "type Myrcia rostrata" (Myrtacaeae) was recorded in samples during four to seven months, but most of these types (89.3\%) occurred only during short periods (Figure 3). 
Table 1. Seasonal variation of monthly mean proportions (\%) of pollen types recorded in larval provisions of Euglossa annectans sampled from 2002-2005 at Santa Catarina Island, southern Brazil.

\begin{tabular}{|c|c|c|c|c|c|c|c|c|c|c|c|}
\hline \multirow[t]{2}{*}{ Taxon } & \multicolumn{11}{|c|}{ Proportion of pollen types (\%) } \\
\hline & $\begin{array}{c}\text { Jan } \\
(\mathrm{N}=2)\end{array}$ & $\begin{array}{c}\text { Feb } \\
(\mathrm{N}=6)\end{array}$ & $\begin{array}{c}\text { Mar } \\
(\mathrm{N}=3)\end{array}$ & $\begin{array}{c}\text { Apr } \\
(\mathrm{N}=10)\end{array}$ & $\begin{array}{l}\text { May } \\
(\mathrm{N}=3)\end{array}$ & $\begin{array}{c}\text { Jun } \\
(\mathrm{N}=2)\end{array}$ & $\begin{array}{c}\text { Jul } \\
(\mathrm{N}=4)\end{array}$ & $\begin{array}{c}\text { Aug } \\
(\mathrm{N}=3)\end{array}$ & $\begin{array}{c}\text { Sep } \\
(\mathrm{N}=3)\end{array}$ & $\begin{array}{c}\text { Oct } \\
(\mathrm{N}=3)\end{array}$ & $\begin{array}{c}\text { Nov } \\
(\mathrm{N}=4)\end{array}$ \\
\hline \multicolumn{12}{|l|}{ Acanthaceae } \\
\hline Thunbergia grandiflora & - & - & - & - & - & - & 0.2 & - & - & - & - \\
\hline \multicolumn{12}{|l|}{ Apocynaceae } \\
\hline Type Prestonia & 0.1 & - & - & - & - & - & - & - & - & - & - \\
\hline \multicolumn{12}{|l|}{ Aquifoliaceae } \\
\hline Type Ilex & - & - & - & - & 0.1 & - & - & - & - & - & - \\
\hline \multicolumn{12}{|l|}{ Arecaceae } \\
\hline Type Bactris & - & - & - & - & - & 0.3 & - & - & - & - & - \\
\hline \multicolumn{12}{|l|}{ Bignoniaceae } \\
\hline Type Jacaranda & - & - & - & - & - & 12.5 & 12.9 & - & - & - & - \\
\hline Pithecoctenium crucigerum & - & 0.3 & - & - & - & - & - & - & 2.2 & - & - \\
\hline Tabebuia impetiginosa & - & - & - & - & 6.3 & - & - & - & - & - & - \\
\hline Tabebuia sp. & - & - & - & 0.1 & - & - & - & - & - & - & - \\
\hline \multicolumn{12}{|l|}{ Bromeliaceae } \\
\hline Bromelia antiacantha & - & - & - & 4.2 & - & - & - & 0.6 & - & - & - \\
\hline Aechmea nudicaulis & - & 0.1 & 4.0 & - & - & - & - & - & - & - & - \\
\hline A. caudata & - & - & - & 3.1 & 0.4 & - & 3.6 & - & - & - & - \\
\hline Type caudata & - & - & - & - & - & - & - & - & 8.8 & 12.3 & - \\
\hline A. lindenii & - & - & - & - & - & - & 1.2 & 9.6 & 44.8 & 22.2 & 0.1 \\
\hline A. ornata & - & - & - & - & 5.8 & 9.7 & 1.6 & 1.6 & 0.4 & - & - \\
\hline Type Neoregelia & - & - & 0.7 & - & 0.5 & - & 0.4 & - & - & - & - \\
\hline Nidularium innocentii & 0.5 & 3.2 & - & 3.1 & - & - & - & 1.8 & - & - & 14.8 \\
\hline Type Vriesea philippocoburgii & ;ii - & - & - & - & - & - & - & - & - & 6.0 & 0.2 \\
\hline Sp 1 & - & - & - & 0.4 & - & - & - & - & - & - & - \\
\hline $\mathrm{Sp} 2$ & - & - & - & - & - & - & 9.4 & 0.1 & 1.7 & - & 0.8 \\
\hline Sp 3 & - & - & - & - & - & - & - & 2.5 & - & - & - \\
\hline \multicolumn{12}{|l|}{ Caesalpiniaceae } \\
\hline Chamaecrista nictitans & - & - & - & - & - & - & 4.6 & - & - & - & - \\
\hline Type Senna sp 1 & - & - & - & 1.3 & - & - & - & - & - & - & - \\
\hline Type Senna sp 2 & - & - & - & - & - & - & - & - & - & 12.8 & 11.7 \\
\hline Type Schizolobium parahyba & - & - & 2.8 & 20.3 & - & - & - & - & - & - & - \\
\hline \multicolumn{12}{|l|}{ Convolvulaceae } \\
\hline Type Aniseia & 0.3 & 0.3 & - & - & - & - & - & - & - & - & - \\
\hline Type Ipomoea sp & - & - & - & - & - & - & 0.2 & - & - & - & - \\
\hline \multicolumn{12}{|l|}{ Cunnoniaceae } \\
\hline Weinmannia paulliniifolia & - & - & - & 1.2 & - & - & - & - & - & - & 0.2 \\
\hline \multicolumn{12}{|l|}{ Euphorbiaceae } \\
\hline Dalechampia sp & - & - & - & - & - & - & - & - & - & 19.7 & - \\
\hline \multicolumn{12}{|l|}{ Fabaceae } \\
\hline Type Lathyrus & 9.8 & 25.7 & 38.6 & 8.8 & 4.8 & - & - & - & - & 17.1 & 21.8 \\
\hline Type Phaseolus & - & - & - & - & - & - & - & 2.6 & - & - & - \\
\hline \multicolumn{12}{|l|}{ Lauraceae } \\
\hline Type Ocotea oblonga & - & - & - & - & - & 23.1 & - & - & - & - & - \\
\hline \multicolumn{12}{|l|}{ Melastomataceae } \\
\hline Clidemia hirta & 4.5 & 0.3 & - & 1.7 & 29.8 & - & - & - & - & - & - \\
\hline Type $C$ lidemia & - & - & - & - & - & - & - & - & - & - & 28.1 \\
\hline
\end{tabular}

Continued on next page 
Table 1. Continued.

\begin{tabular}{|c|c|c|c|c|c|c|c|c|c|c|c|}
\hline \multirow[t]{2}{*}{ Taxon } & \multicolumn{11}{|c|}{ Proportion of pollen types (\%) } \\
\hline & $\begin{array}{c}\text { Jan } \\
(\mathrm{N}=2)\end{array}$ & $\begin{array}{c}\text { Feb } \\
(\mathrm{N}=6)\end{array}$ & $\begin{array}{c}\text { Mar } \\
(\mathrm{N}=3)\end{array}$ & $\begin{array}{c}\text { Apr } \\
(\mathrm{N}=10)\end{array}$ & $\begin{array}{c}\text { May } \\
(\mathrm{N}=3)\end{array}$ & $\begin{array}{c}\text { Jun } \\
(\mathrm{N}=2)\end{array}$ & $\begin{array}{c}\text { Jul } \\
(\mathrm{N}=4)\end{array}$ & $\begin{array}{c}\text { Aug } \\
(\mathrm{N}=3)\end{array}$ & $\begin{array}{c}\text { Sep } \\
(\mathrm{N}=3)\end{array}$ & $\begin{array}{c}\text { Oct } \\
(\mathrm{N}=3)\end{array}$ & $\begin{array}{c}\text { Nov } \\
(\mathrm{N}=4)\end{array}$ \\
\hline Type Leandra & - & - & - & - & - & - & 2.2 & - & - & - & - \\
\hline Miconia sp & - & - & - & - & 27.9 & 33.1 & - & - & - & 1.2 & - \\
\hline Tibouchina mutabilis & - & - & 0.1 & - & - & - & - & - & - & - & - \\
\hline Type T. mutabilis & - & - & - & - & - & - & - & - & - & - & 10.4 \\
\hline Tibouchina urvilleana & 5.6 & 2.4 & - & - & - & 19.2 & - & - & - & - & - \\
\hline Tibouchina versicolor & - & - & - & - & 1.1 & 1.6 & - & - & - & - & - \\
\hline Sp 1 & - & - & - & - & - & - & 23.5 & - & - & - & - \\
\hline $\mathrm{Sp} 2$ & - & - & - & - & - & - & 32.6 & 12.8 & - & - & - \\
\hline Sp 3 & - & - & - & - & - & - & - & - & - & 7.0 & - \\
\hline \multicolumn{12}{|l|}{ Mimosaceae } \\
\hline Mimosa bimucronata & - & - & 37.2 & - & - & - & - & - & - & - & - \\
\hline \multicolumn{12}{|l|}{ Myrtaceae } \\
\hline Eugenia cf. umbelliflora & - & - & - & 55.0 & - & - & 6.8 & - & - & 0.7 & - \\
\hline Gomidesia sp. & 25.4 & & & & & & & & & & 0.1 \\
\hline Type Myrcia rostrata & - & 17.2 & 1.4 & - & - & - & - & - & - & 0.1 & 0.1 \\
\hline Psidium guajava & - & - & - & - & - & - & - & - & - & - & 2.6 \\
\hline Type Psidium & - & - & - & - & - & - & - & - & - & 0.8 & - \\
\hline Syzygium jambolanum & - & - & - & - & 0.2 & - & - & - & - & - & - \\
\hline Type Syzygium & 7.8 & & - & - & 0.3 & - & - & 37.9 & - & - & - \\
\hline Sp 2 & - & - & - & - & - & 0.2 & - & - & - & - & - \\
\hline Sp 3 & - & - & - & - & - & - & 0.5 & - & - & - & - \\
\hline Sp 4 & - & - & - & - & - & - & - & 7.5 & - & - & - \\
\hline Sp 5 & - & - & - & - & - & - & - & - & 3.7 & - & - \\
\hline \multicolumn{12}{|l|}{ Ochnaceae } \\
\hline Type Ouratea 1 & 25.8 & 36.3 & 4.2 & - & - & - & - & 21.8 & 19.5 & - & - \\
\hline Type Ouratea 2 & 20.5 & 14.6 & 9.5 & - & - & - & - & - & - & - & - \\
\hline Sp 1 & - & - & 0.1 & - & - & - & - & - & - & - & - \\
\hline \multicolumn{12}{|l|}{ Polygonaceae } \\
\hline Type Polygonum & - & - & - & - & 0.3 & - & - & 1.2 & - & - & - \\
\hline \multicolumn{12}{|l|}{ Rubiaceae } \\
\hline Psychotria sp & - & - & 0.5 & - & - & 0.5 & 0.3 & - & - & - & - \\
\hline \multicolumn{12}{|l|}{ Sapindaceae } \\
\hline Type Allophylus & - & - & 0.9 & - & - & - & - & - & - & - & - \\
\hline \multicolumn{12}{|l|}{ Solanaceae } \\
\hline Solanum cf. mauritanium & - & - & - & 0.8 & - & - & - & - & - & - & - \\
\hline Type Solanum & - & - & - & - & 22.6 & - & - & - & - & - & - \\
\hline Solanum americanum & - & - & - & - & - & - & - & - & - & - & 10.6 \\
\hline Sp 1 & - & - & - & - & - & - & - & - & 0.7 & - & - \\
\hline Not identified 1 & - & 0.1 & - & - & - & - & - & - & - & - & - \\
\hline Not identified 2 & - & - & - & - & 0.4 & - & - & - & - & - & - \\
\hline Not identified 3 & - & - & - & - & - & - & 0.2 & - & - & - & - \\
\hline Not identified 4 & - & - & - & - & - & - & 0.3 & - & - & - & - \\
\hline Not identified 5 & - & - & - & - & - & - & - & 0.1 & - & - & - \\
\hline Not identified 6 & - & - & - & - & - & - & - & - & 0.1 & - & - \\
\hline Not identified 7 & - & - & - & - & - & - & - & - & 17.7 & - & - \\
\hline Not identified 8 & - & - & - & - & - & - & - & - & 0.3 & - & - \\
\hline Not identified 9 & - & - & - & - & - & - & - & - & - & - & 0.1 \\
\hline Pollen types per month & 10 & 11 & 12 & 12 & 14 & 9 & 17 & 13 & 11 & 11 & 14 \\
\hline
\end{tabular}




\section{Pollen types over $10 \%$ monthly proportion}

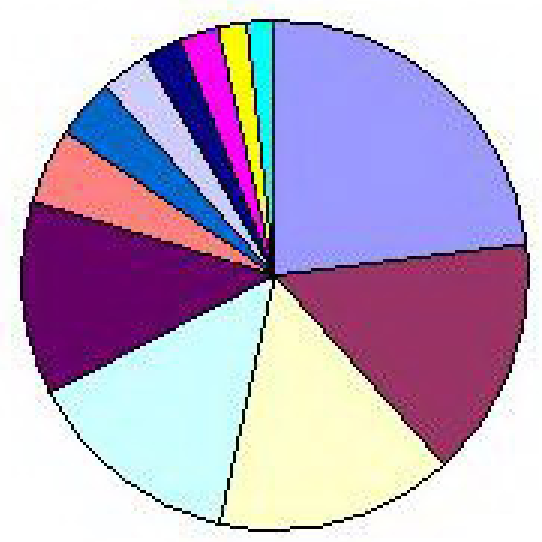

$\checkmark$ Melas tomatacese: Clideria hirta, type Clidemis, Miconia s p type T. mutabili, T. urvilleans, sp $1, \operatorname{sp} 2$.

口 Myrta cese: Eugenia of. umbelifbra, Gomides is sp, type Myrcia ros trats, type Syz igium

口 Ochnaceae: type Ouratea 1, ty pe Ouratea 2

口 Bromeliaceae: ty pe A. caudata, A. Indenii, A. or nata, Nidular ium innocenti

- Fabaceae: type Lathyrus

$\square$ Caes alpin iacese: type Senna 2, type Schizolobium parahy bum

- Mimos ace ae: Mimos a bimucrongta

口 Solanaceae: type Solanum, Solanum americanum

- Bignoniaceae: ty pe Jacarands

- Louracese: ty pe Ocotes oblongs

口 Elphorbiaceae: Dalechampia sp

not identified 7

Figure 2. Proportions of pollen types represented over $10 \%$ in at least one month in brood cells of Euglossa annectans at Santa Catarina Island between 2002-2005. 


\section{Seasonal variation of main pollen types}

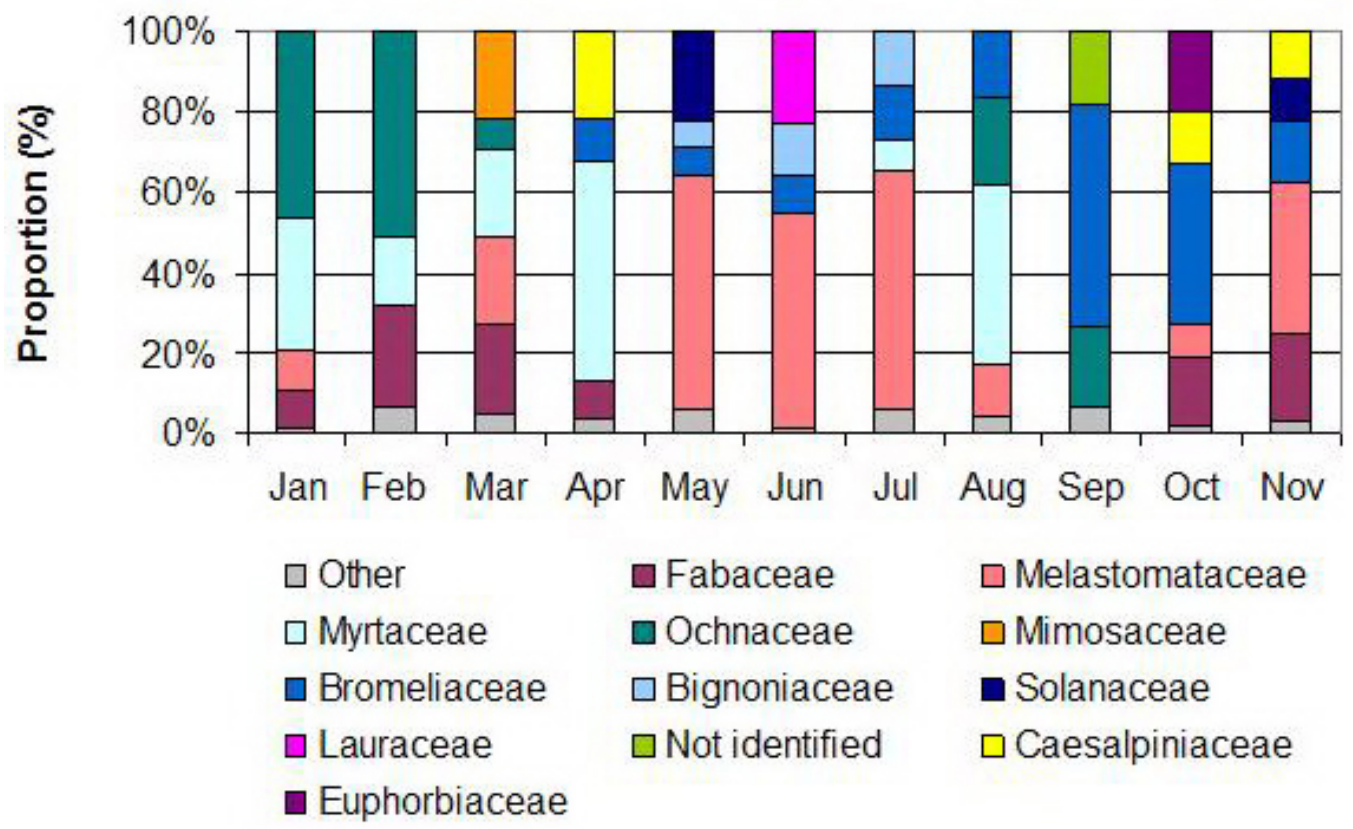

Figure 3. Monthly representation of main plant families (monthly means $>5 \%$ ) in pollen provisions from brood cells of Euglossa annectans at Santa Catarina Island, southern Brazil.

The diversity index H' per brood cell $(\mathrm{N}=43)$ varied from $0.10-1.65$ (Table 2) and monthly means from 0.71-1.47 (Table 2). Highest diversity indices resulted from pollen samples taken in October, November and January.

Table 2. Monthly variation of Shannon-Weaver diversity indices (H') of the pollen types recorded from brood cell provisions of Euglossa annectans on Santa Catarina Island, southern Brazil.

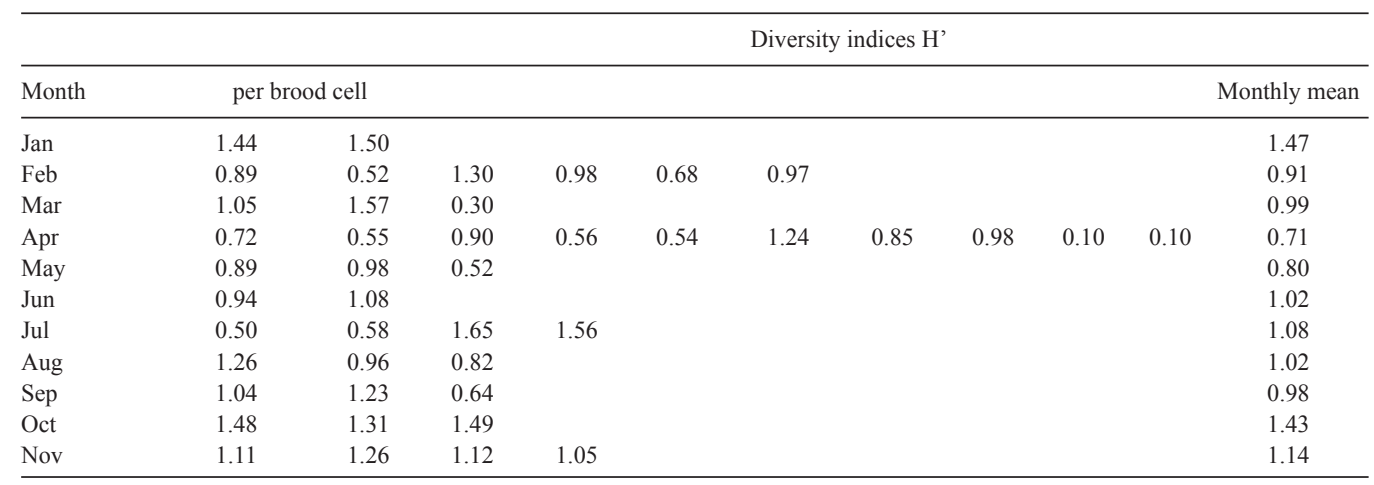


Similarity indices varied between 0 and 0.87 , with the highest mean values in January, February, March, April, and October (Table 3).

\begin{tabular}{|c|c|c|c|}
\hline \multirow[t]{2}{*}{ Month } & \multirow{2}{*}{$\begin{array}{c}\text { Brood cell } \\
\text { numbers }\end{array}$} & \multicolumn{2}{|c|}{ Similarity index } \\
\hline & & Range & Monthly mean \\
\hline Jan & 2 & 0.57 & 0.57 \\
\hline Feb & $6^{*}$ & $0.38-0.85$ & 0.60 \\
\hline Mar & $3^{*}$ & $0.34-0.80$ & 0.55 \\
\hline Apr & $10 *$ & $0.18-0.83$ & 0.47 \\
\hline May & 3 & $0.15-0.37$ & 0.43 \\
\hline Jun & 2 & 0.20 & 0.20 \\
\hline Jul & $4 *$ & $0.18-0.56$ & 0.30 \\
\hline Aug & $3 *$ & $0.00-0.68$ & 0.23 \\
\hline Sep & 3 & $0.31-0.40$ & 0.35 \\
\hline Oct & 3 & $0.54-0.87$ & 0.67 \\
\hline Nov & 4 & $0.56-0.60$ & 0.42 \\
\hline
\end{tabular}

*Samples from the same nest box.

\section{DISCUSSION}

The wide spectrum of plant families used as pollen resources characterizes $E$. annectans as a highly polylectic bee species. In Mexico $\left(15^{\circ} 05^{\prime} \mathrm{N} ; 92^{\circ} 31^{\prime} \mathrm{W}\right)$, E. atroveneta showed the same generalistic behavior collecting pollen from 71 plant species along the year (Ramírez-Arriaga and Martínez-Hernández, 1998). This generalistic foraging behavior is typical for the corbiculate Apidae, most of which are social to a certain degree.

Among the most frequent plant families in the pollen diet of $E$. annectans, the species of Melastomataceae, Bromeliaceae and Myrtaceae show a sequential flowering along the year (Araújo et al., 2004; Harter-Marques et al., 2005). In Melastomataceae, the annual sequence starts with the flowering of Clidemia and Tibouchina in summer, followed by, Miconia and Tibouchina in autumn and winter, and ends with Leandra, Tibouchina in winter and spring. The myrtacean species Gomidesia and the types Myrcia and Syzygium bloom in summer, Eugenia and Syzygium in autumn and type Syzygium and Psidium sp in spring. Inventories performed in the Atlantic forest in São Paulo State revealed that Myrtaceae often occurred in highest abundance and species richness (Mamede et al., 2004). Bromeliad species flowering in summer are $N$. innocentii and type Neoregelia, followed by A. caudata and A. ornata in autumn and winter and $A$. lindenii, and the types $A$. caudata/Vriesea philippocoburgii in winter and spring. This family is characteristic for the Neotropical region and is a highly diverse and abundant group in the Brazilian Atlantic rainforest (Fischer and Araújo, 1996). Many bromeliad species present an ornithophilous flower syndrome suggesting that hummingbirds are the principal pollinators of their narrow tubular flowers. However, bees also exploit the floral resources of bromeliads, and especially the long-tongued species like euglossines are able to cope with the specialized flower morphology (Dorneles, 2006; Grohme et al., 2008). In contrast to our findings, bromeliad pollen was not recorded in the provisions of Euglossa atroveneta in Mexico. Similarity to the Mexican species E. atroveneta consists mainly in the 
use of pollen from plants in the families Myrtaceae (genus Eugenia), Melastomataceae (genus Tibouchina), Euphorbiaceae (genus Dalechampia), and Solanaceae (genus Solanum).

Among the most frequently recorded plant species, Dalechampia sp stands out because species of Euglossa have been reported as their pollinators in several places within the Neotropical region, from Mexico (Armbruster and Webster, 1979), and Amazonia (Armbruster and Webster, 1981) to southern Brazil (Sazima et al., 1985).

The pollen classified as "type Lathyrus sp" (Fabaceae) was very frequent in pollen provisions and perhaps originates from some cultivated legume growing in plantations adjacent to the study areas. Considering the global pollinator crisis, the question whether $E$. annectans is an effective pollinator of regional agricultural crops deserves attention and future studies in Brazil.

Also the visitation to flowers of Ocotea oblonga suggests that E. annectans possibly pollinate them. Since species of Ocotea are typical for mature Atlantic rainforest such a mutualism may prove to be essential for conservation and self-regeneration of this biodiversity hotspot (Myers et al., 2000).

We compiled published records on plants visited by Euglossa bees from different biomes in Brazil (Figure 4). The plants belonged to 85 species and 24 families and again, species of Fabaceae, Bignoniaceae and Melastomataceae were among the most frequently recorded. Roubik and Hanson (2004) and Ramirez et al. (2002) listed, respectively, 68 and 65 plant species visited by euglossines in Tropical America. These latter pooled data underestimated the diversity of flowers visited by the genus Euglossa if one considers the high polylectic rank of E. annectans.

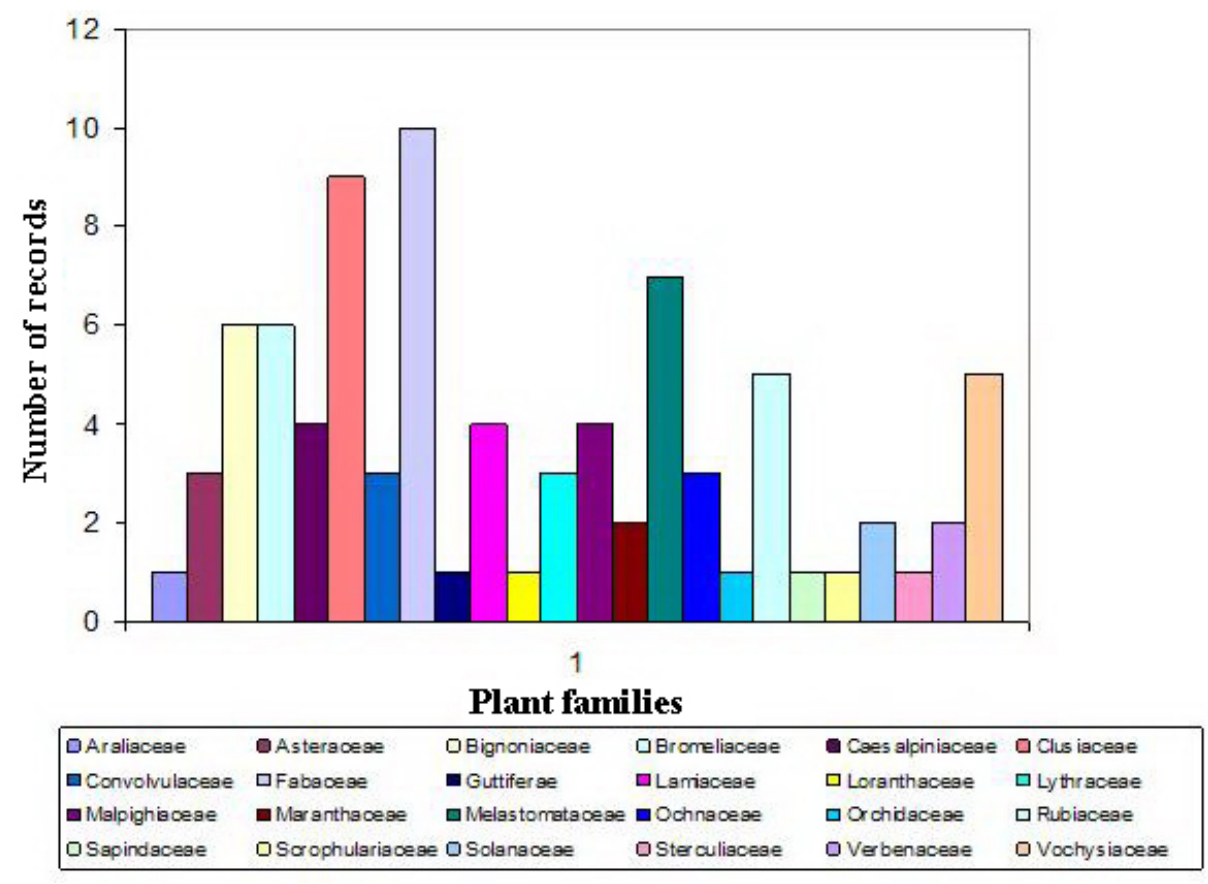

Figure 4. Frequency of Euglossa bees recorded on flowers of different plant families in several biomes of Brazil (summarized published data). 
The Shannon-Weaver diversity indices show that the content of the brood cells is not homogeneous but typically consists of several quite distinct pollen types. In fact, there was only one cell, which contained predominantly pollen of a single plant species. This diversity is therefore the result of a foraging behavior that is not only polylectic along the year but also within the few days in which one brood cell is provisioned. Whether the E. annectans females present preferences for certain pollen sources or whether they just collect opportunistically on the most available flowerings would require further field observations on foraging behavior.

In the course of a year, highest diversity indices resulted from samples taken in October, November and January. This is probably due to the fact that the number of flowering species increases in spring/summer and perhaps because of a stronger competition with other insects during the warmer season, as has been observed in social meliponids and Apis mellifera (Cortopassi-Laurino and Ramalho, 1988).

Similarity of pollen sources between brood cells varied widely ranging from complete difference to almost complete overlap, but similarity indices between contemporaneous brood cells from the same nest were not higher than those from different nests. Pollen diversity per contemporaneous brood cells also varied within a very wide range, and mean diversity indices per month varied within a narrower range than those per brood cell, in the annual cycle. Ramírez-Arriaga and Martínez-Hernández (1998) reported very similar diversity data for $E$. atroveneta. These findings suggest that contemporaneous females of $E$. annectans from the same nest likely choose their pollen sources independently of each other. More specifically, pollen source similarity and diversity data support the opportunistic foraging hypothesis. Contrasting with the frequent use of pollen sources from some plant families, flower preferences likely play a minor role in foraging decisions in the annual cycle.

\section{ACKNOWLEDGMENTS}

We are indebted to the late Maike Hering de Queiroz and Antônio Diomário de Queiroz for allowing us to work on their property and in the UCAD, to Daniel de Barcellos Falkenberg, UFSC, for the identification of plant species, to Silvânio G. da Costa for information on the UCAD, and to Rafael Kamke, Livia Dorneles, and Eliana de Medeiros Oliveira for their help in preparing and organizing the pollen reference collection. This study is part of the project "Importância das bromélias para a manutenção da biodiversidade da fauna associada na "Mata Atlântica" Internal dynamics of rain forest: specificity of animal-plant interaction" within the Brazilian-German program "Mata Atlântica", and we acknowledge the financial support by BMBF (\#01LB0205) and CNPq (\#690143/01-0), as well as the equipment funded by IFS. We thank CNPq for a grant to M. Cortopassi-Laurino (\#39 0270/05-9).

\section{REFERENCES}

Araújo AC, Fischer E and Sazima M (2004). As Bromélias na Região do Rio Verde. In: Estação Ecológica Juréia-Itatins. Ambiente Físico, Flora e Fauna (Marques OAV and Duleba W, eds.). Holos, Ribeirão Preto, 162-171.

Armbruster WS and Webster GL (1979). Pollination of two species of Dalechampia (Euphorbiaceae) in Mexico by Euglossine bees. Biotropica 11: 278-283.

Armbruster WS and Webster GL (1981). Sistemas de polonização de duas espécies simpátricas de Dalechampia (Euphorbiaceae) no Amazonas, Brasil. Acta Amazon. 11: 13-17.

Augusto SC and Garófalo CA (2004). Nesting biology and social structure of Euglossa (Euglossa) townsendi Cockerell 
(Hymenoptera, Apidae, Euglossini). Insectes Soc. 51: 400-409.

Barth MO (1989). O Pólen no Mel Brasileiro. CNPq/FIOCRUZ, Rio de Janeiro.

Cody ML (1974). Competition and the Structure of Bird Communities. Princeton University Press, Princeton.

Cortopassi-Laurino M and Ramalho M (1988). Pollen harvest by Africanized Apis mellifera and Trigona spinipes in São Paulo botanical and ecological views. Apidologie 19: 1-24.

Cortopassi-Laurino M, Dorneles LL, Zillikens A and Steiner J (2008a). Utilização de Recursos Florais por Euglossa annectans (Hymenoptera, Apidae, Euglossini). Anais do VIII Encontro Sobre Abelhas, CD-Rom, Ribeirão Preto.

Cortopassi-Laurino M, Hilário SD, Ribeiro MF and Nogueira-Neto P (2008b). Longevidade e Tamanho de um Ninho Gregário de Euglossa annectans Dresler 1982 em Área Urbana. Anais do VIII Encontro Sobre Abelhas, CD-Rom. Ribeirão Preto.

Dorneles LL (2006). Biologia da Polinização de Aechmea lindenii (Bromeliaceae) e as Fontes Florais de Alimento Utilizadas por Euglossa annectans (Apidae, Euglossina) em Áreas Florestais da Ilha de Santa Catarina. Monografia Apresentada ao Curso de Ciências Biológicas, UFSC, Florianópolis.

Engel MS (1999). The first fossil Euglossa and phylogeny of the orchid bees (Hymenoptera: Apidae; Euglossini). Am. Mus. Novit. 3272: 1-14.

Fischer AE and Araújo AC (1996). A flora de bromélias no estuário do Rio Verde (Juréia, São Paulo): uma comparação com outras comunidades neotropicais. Bromélia 3: 19-25.

Garófalo CA, Camilo E, Araújo AC, Jesus BMV, et al. (1998). Nest structure and communal nesting in Euglossa (Glossura) annectans Dressler (Hymenoptera, Apidae, Euglossini). Rev. Bras. Zool. 15: 589-596.

Grohme S, Zillikens A and Steiner J (2008). Diversity, Foraging Behaviour and Diel Pattern of Bees Visiting Flowers of Aechmea nudicaulis (Bromeliaceae) on Santa Catarina Island, Southern Brazil. Anais do VIII Encontro Sobre Abelhas, CD-Rom, Ribeirão Preto.

Harter-Marques B, Dorneles LL, Steiner J and Zillikens A (2005). Fenologia da Floração e Visitantes Florais de Seis Espécies de Bromeliaceae da Ilha de Santa Catarina. In: $56^{\circ}$ Congresso Nacional de Botânica, Anais eletrônicos. SBB, CD-Rom, Curitiba.

Mamede MCH, Cordeiro I, Rossi L, Melo MMRF, et al. (2004). Mata Atlântica. In: Estação Ecológica Juréia-Itatins. Ambiente Físico, Flora e Fauna (Marques OAV and Duleba W, eds.). Holos, Ribeirão Preto, 115-132.

Myers N, Mittermeier RA, Mittermeier CG, da Fonseca GA, et al. (2000). Biodiversity hotspots for conservation priorities. Nature 403: 853-858.

Moreti ACCC, Marchini LC, Souza VC and Rodrigues RR (2002). Atlas do Pólen de Plantas Apícolas. FAPESP/Virtual (Incubadora Virtual da Fapesp), Rio de Janeiro.

Moure JS, Urban D and Melo GAR (2007). Catalogue of Bees (Hymenoptera, Apoidea) in the Neotropical Region. SBE (Sociedade Brasileira de Entomologia), Curitiba.

Otero JT, Ulloa-Chacón P, Silverstone-Sopkin P and Giray T (2008). Group nesting and individual variation in behavior and physiology in the orchid bee Euglossa nigropilosa Moure (Hymenoptera, Apidae). Insectes Soc. 55: 320-328.

Ramírez-Arriaga E and Martínez-Hernández E (1998). Resources foraged by Euglossa atroveneta (Apidae: Euglossinae) at Union Juárez, Chiapas, Mexico. A palynological study of larval feeding. Apidologie 29: 347-359.

Ramírez S, Dressler R and Ospina M (2002). Abejas euglosinas (Hymenoptera: Apidae) de la Región Neotropical: Listado de especies con notas sobre su biología. Biota Colomb. 3: 7-118.

Roubik DW and Moreno JE (1991). Pollen and spores of Barro Colorado Island. Monogr. Syst. Bot. 36: 1-268.

Roubik DW and Hanson PE (2004). Abejas de Orquídeas de la América Tropical. Biologia y Guía de Campo. Editora INBio, Santo Domingo de Heredia, Costa Rica.

Santos CFO (1963). Características morfológicas dos grãos de pólen das principais plantas apícolas. An. ESALQ 20: 175-228.

Sazima M, Sazima I and Carvalho-Okano RM (1985). Biologia floral de Dalechampia stipulaceae (Euphorbiaceae) e sua polinização por Euglossa melanotricha (Apidae). Rev. Bras. Zool. 45: 85-93.

Shannon CE and Weaver W (1949). The Mathematical Theory of Communication. University of Illinois Press, Urbana.

Soucy SL, Giray T and Roubik DW (2003). Solitary and group nesting in the orchid bee Euglossa hyacinthina (Hymenoptera, Apidae). Insectes Soc. 50: 248-255.

Zillikens A and Steiner J (2004). Nest Architecture, life cycle and cleptoparasite of the Neotropical leaf-cutting bee Megachile (Chrysosarus) pseudanthidioides Moure (Hymenoptera: Megachilidae). J. Kansas Entomol. Soc. 77: 193-202.

Zillikens A, Kamke R and Steiner J (2003). Communal nesting in orchid bees - co-operation or competition? Rev. Etol. (Suppl) 5: 224-225.

Zucchi R, Sakagami SF and Camargo JMF (1969). Biological observations on a tropical parasocial bee, Eulaema nigrita, with a review on the biology of Euglossinae (Hymenoptera, Apidae). J. Fac. Sci. Hokkaido Univ. (Series IV, Zool.) 17: 271-380. 